\title{
Comprehending Antisemitism through the Ages: Introduction
}

Robert Wistrich's definition of antisemitism as the "longest hatred" carries as much weight now as it did thirty years ago, when Wistrich published his landmark study. Today, in our contemporary societies and culture, antisemitism is on the rise, and its manifestations are manifold. Antisemitic hate crimes have spiked in recent decades, and antisemitic stereotypes, sentiments, and hate speech have permeated all parts of the political spectrum. In order to effectively counteract the ever-growing Jew-hatred of our times, it is important to recognise the traditions that have fed antisemitism throughout history. Antisemitism is an age-old hatred deeply embedded in societies around the globe. While the internet and modern media have contributed beyond measure to the increase of Jewhatred in all parts of the world, the transformation processes that antisemitism has been undergoing through the ages remain the same. A core condition of antisemitism is its versatile nature and adaptability, both of which can be traced through all periods of time. Current-day antisemitism is shaped and sustained not only by powerful precedents but also reflects common fears and anxieties that our societies are faced with in a world that is ever changing and where the changes run even faster today than ever before. Historical awareness of the nature of antisemitism, therefore, is more important than ever. The present volume, thus, wants to help raise this awareness. Its articles trace the history of antisemitism and the tradition of antisemitic stereotypes through the ages. It documents various manifestations of antisemitism over time and reflects on the varying motivations for antisemitism. As such, these contributions shed light on socio-cultural and socio-psychological processes that have led to the spike of antisemitism in various periods of time and in varying intensity. In this way, they can help to establish methods and policies to not only to counter current antisemitic manifestations but also to combat them.

\section{Terminology and Historiographical Delineation}

The usage of the term antisemitism is much debated in historical scholarship. Various scholars claim that the term reflects a conceptualisation of Judaism as

1 R. S. Wistrich, Antisemitism: The Longest Hatred (London: Methuen, 1991).

Ә OpenAccess. () 2021 Kerstin Mayerhofer and Armin Lange, published by De Gruyter. 
a race, which can only be understood in the context of nationalism and racial theory in the early nineteenth century. ${ }^{2}$ Earlier forms of Jew-hatred are therefore mostly referred to as "anti-Judaism," therein reflecting theological concepts. Christian religious stereotypes of Jews are largely connected to doctrines of false beliefs and practices competing with Christianity. However, much of Christian polemic directed against Jews expresses negative images and attitudes in a way that reaches far beyond the scope of religious alterity. The frequent claim that calling pre-modern Jew-hatred antisemitic is an anachronism can only be accepted with regards to terminology. In fact, the term antisemitism did not come into existence and has not been used to describe Jew-hatred before the nineteenth century. Various forms of persecution of the Jews not solely based on religious grounds, however, can be traced back well into ancient times.

Despite the conference being based on the IHRA's Working Definition of Antisemitism, ${ }^{3}$ several contributions employ different definitions of antisemitism. While some essays perceive all forms of Jew-hatred and anti-Jewish discrimination as antisemitic, others are more restrictive in their use of the term antisemitism as mentioned above.

A volume that tries to trace the historical roots of antisemitism cannot do so without a delineation of the historical periods it discusses. The history of antisemitism evolves in accordance with socio-political processes as well as alongside certain cultural events shaping the histories of thought and culture. The editors of the present volume have chosen to structure the volume accordingly: (1) Ancient and Late Ancient Times, from the end of the Iron age, ca. 550 B.C.E., to the period of early Muslim conquests in Western Europe ca. 630 800 C.E. (2) Medieval Times until the invention of the printing press, c. 1440, as a technique that had a significant influence on both the history of thought and the history of socio-cultural and socio-political ideologies. (3) Modern Times starting with the American and the French revolutions of the years 1775 - 1783 and 1789 - 1799, respectively. (4) An era of "New Antisemitism" follow-

2 Cf. e.g. W. Bergmann, Geschichte des Antisemitismus (München: C. H. Beck, 2002); C. Guillaumin, L'idéologie raciste: Genèse et langage actuel (Paris: Gallimard, 1972); J. Heil, “'Antijudaismus' und 'Antisemitismus': Begriffe als Bedeutungsträger," Jahrbuch für Antisemitismusforschung 6 (1997): 92-114; G. I. Langmuir, Toward a Definition of Antisemitism (Berkeley: University of California Press, 1990); T. Nipperdey and R. Rürup, “Antisemitismus,” in Geschichtliche Grundbegriffe: Historisches Lexikon zur politisch-sozialen Sprache in Deutschland, ed. 0. Brunner, W. Conze, and R. Koselleck (Stuttgart: Klett-Cotta, 1972), 129-53.

3 For further detail, refer to volume 1 of the present series, A. Lange, K. Mayerhofer, D. Porat, and L. H. Schiffman, eds., Comprehending and Confronting Antisemitism: A Multi-Faceted Approach, vol. 1 of An End to Antisemitism! (Berlin: De Gruyter, 2019), 565-67. 
ing the Shoah, with a subdivision (5) about Anti-Zionism as a most virulent manifestation of this "New Antisemitism."

Two insufficiencies have to be admitted in this structure. First, certain historical periods and events are not addressed, for example, early modern times or the Spanish Inquisition. This is mainly due to the fact that several colleagues who covered these fields at the conference were not able to contribute to the present volume. Second, the perspective from which contributors to the present volume reflect on the history of antisemitism is rather Eurocentric. Much of the history of Jew-hatred documented in the present volume focuses on the geographical regions of Western Europe. Discussions of antisemitism in the United States and reflections on anti-Zionism directed against Israel are a geographical exception. However, these articles too are based largely on a European discourse of thought. Unfortunately, a single volume can hardly take all global aspects into consideration. Therefore, several of the missing topics, such as Islam or a variety of manifestations of "New Antisemitism," are addressed in volumes 2 and 5 of the present series. ${ }^{4}$ Still, the editors of the present volume are aware that the historical picture of antisemitism in this volume is by necessity incomplete and, thus, sometimes ambiguous.

\section{Claiming Authority and Appealing to Emotions}

When working on the history of antisemitism, two different aspects need to be taken into consideration with regards to the transmission and evaluation of antisemitic stereotypes and traditions. Antisemitic stereotypes and traditions can be transmitted in the form of an authorizing re-writing, that is, with references to older source material. Early modern and modern thinkers who fostered antisemitic sentiments were keen on attributing their own antisemitic polemic to a pseudo-scientific discourse. In referencing a canon of antisemitic stereotypes and traditions, which had been transmitted from late ancient and medieval times, early modern writers ensured continuity for their own antisemitic thoughts and claims. An important example for this practice can be found in Antonius Margaritha's (1492/8-1542) treatise of 1530, titled The Entire Jewish Faith. ${ }^{5}$ Having once experienced doubt in

4 Cf. A. Lange, K. Mayerhofer, D. Porat, and L. H. Schiffman, eds., Confronting Antisemitism from the Perspectives of Christianity, Islam, and Judaism, and ibid., Confronting Antisemitism in Modern Media, the Legal and Political Worlds, vols. 2 and 5 of An End to Antisemitism! (Berlin: De Gruyter, 2020 and 2021).

5 Cf. Antonius Margaritha, Der gantz Jüdisch Glaub mit sampt ainer gründtlichen und warhafften Anzaygunge ... (Augsburg: Heinrich Steiner, 1530). 
his own faith, as a convert from Judaism to Christianity, Margaritha was able to turn both to doubting Christians in an effort to strengthen their belief but also to Jews in an attempt to convince them to follow his own path to Christianity. His depiction of Jewish rituals, customs, and ceremonies in The Entire Jewish Faith is accurate. However, Margaritha's main objective is a presentation of Judaism as a religion that had failed to understand and accept God's true revelation and, thus, poses a danger to the Christian faith. For this purpose, Margaritha drew on a vast canon of medieval polemic against Jews, on antagonistic narratives, motifs, and imagery of Jews as friends of the devil, aggressors against Christ's body, and as murderers of Christian children. Superstitions and further stereotypes, some theologically motivated and some not, were used to demonstrate the Jews' ongoing religious inferiority as proof and reason for their socio-economic and legal marginalisation.

Many early modern thinkers and writers followed Margaritha's example and support a discourse of religious and socio-cultural superiority of one religiocultural group over another. An example is the ongoing conflict between Catholics and Protestants in early modern and modern times and their fight for political supremacy, which motivates an extensive engagement with the Jews as their common age-old opposite. Whether within the frame of the doctrinal battle between Catholics and Protestants or not, Judaism was regarded as inferior, and Jews were subjected to discrimination, marginalisation, and subordination. Theological and, increasingly, sociological and pseudo-scientific disputes corroborated processes of identity formation-first, on a religious level but subsequently also within the contexts of nation and race. These contexts gained importance especially at the turn of the eighteenth and nineteenth centuries when new theories on human thought and race had emerged. Social Darwinism and racism greatly influenced antisemitic thinkers such as Carl Wilhelm Friedrich Grattenauer (1773-1838), Achim von Arnim (1781-1831), and Clemens Brentano (1778-1842) who found their own antisemitic beliefs confirmed by these theories and, subsequently, referenced them to increase the authority and significance of their polemics. Concepts of social norms were established and projected back onto specific ways of life, expressions of thought and signs of the body. Notions of a distorted and diseased "Jewish body," which is considered the result of a false religious, cultural, and social lifestyle, were shaped extensively during this period but stand in the tradition of medieval ChristianJewish polemic. During modern times, however, they were considered less as the result of divine punishment, but were rather interpreted as reflecting a specific mindset and lifestyle as well as anthropological conditions.

Referencing earlier sources and incorporating pseudo-scientific theories of nation, race, and biology into polemical writing helped to create authority when appealing to one's audience. Methods like these were and are used to 
file specific socio-political or socio-economical claims and support processes of formation or strengthening of specific group-identities vis-à-vis a proclaimed inferior opposite. They shape political processes and legal regulations directed against such alleged inferior groups. Antisemitic agitation, however, can take yet another form-as an appeal to emotion. Stereotypes and discriminatory claims about the Jews' corrupt nature and diseased bodies, for example, are shaped as "arguments from passion" that aim to manipulate a recipient's emotions in order to convince them of polemical content. Antisemitic polemic appeals especially to feelings of fear and anxiety as well as of anger and pride. This becomes rather apparent when antisemitic stereotypes are mutually exclusive and shift radically across time and space-examples include the condemnation of Jews as radical communists and as avaricious capitalists at the same time. In cases like these, Jews become a target for the projection of a non-Jewish group's fears arising especially during times of social disruption. Antisemitism as a social phenomenon appealing to emotions can be witnessed throughout the ages from the fall of the Roman Empire, to the time of the Crusades, from the era of the Black Death to the Franco-Prussian War, following World War I, during the Depression in the United States or in the Soviet Union throughout the Cold War years. In the last decades, the spike of Muslim antisemitism, too, can be connected to social and political changes in the Arab world that lead to increased fear, anxiety, and anger among their civil societies.

Processes of claiming authority and of appealing to emotions can be witnessed among antisemitic thinkers until today. Leading figures of openly antisemitic groups tend to authorise their polemic claims in reference to earlier sources. They try to legitimise contemporary antisemitic discrimination and persecution by referencing ancient and medieval stereotypes of the Jews as economic exploiters and as antisocial, evil members of society. Pseudo-scientific arguments of the Jews as a "lesser race" in accordance with modern racist and nationalist thinking conflate with these groups' own emotionally charged reservation against Jews. Such polemics become all the more dangerous when coming from a person who claims scholarly authority, as in the case of Thomas Dalton. Dalton claims to be a professor of humanities at a major US university and has published extensively on the history of antisemitism, the Shoah, and the National Socialist era from a clearly antisemitic point of view. His publications appear in white nationalist presses and journals. He has translated multiple works from National Socialist thinkers, among them also Hitler's Mein Kampf and contemporary pro-Nazi historians. In conflating his alleged scholarly knowledge with his own emotionally charged polemics against Jews, Dalton reaches many followers who are willing to attribute a great importance and historical diligence to both his work and his antisemitic polemic. On the other hand, antisemitic agitators 
such as the website smoloko.com, poisoned their followers' minds without any need for further academic, scientific, or historical accuracy and authority. Caricatures, graphics, memes, and short polemical texts were often radical and sensational, sometimes even including pornographic elements, and appeal to their recipients' emotions of fear, anxiety, anger, and pride to create an atmosphere of resentment which, in turn, also functions as the shared feeling to keep the hate group together. Both processes-claiming historical and scholarly authority and appealing to emotion-often intersect and link to take extreme forms in violent attacks against Jewish life and institutions. This has recently been the case with, for example, Robert G. Bowers who was responsible for the Pittsburgh synagogue shooting in 2018. His terrorist attack was both religiously motivated and fuelled by consuming both emotionally charged polemics online and pseudo-scientifically authorised writing.

\section{Definition, Transformation, Motivation}

Based on these aspects of antisemitic traditions through the ages, in addressing the history of antisemitism the present volume has a triple focus. As a first major topic, its contributions address the definition of antisemitism itself. As mentioned above, different articles in the present volume apply different definitions of antisemitism understanding it as a form discrimination based on religion, race, or an intersectional canon of determinatory categories of identity. The articles of this volume apply their terminology accordingly. However, what unifies the articles dealing with the definition of antisemitism is a historiographical approach. They do not only theoretically reflect on questions of identity and racism but also discuss their historical beginnings, transmission, and transformations. The latter is the present volume's second major focus.

The history of antisemitism is characterised by multiple transformations and its overall versatile nature. Religiously motivated resentments against Jews as adherents to an outdated faith who allegedly murdered Christ helped to shape European Christian identities. Ideas of hereditary inferiority of certain groups of people have greatly contributed to this process of identity formation, not only within Christianity. Antisemitism has taken different forms accordingly, from religious to cultural hatred and persecution in the beginning, and resulting in increased socio-political persecution and the curtailment of economic, political, and legal advancement of Jews beginning already in pre-modern times. Physical aggression and violence against Jews and their institutions, such as synagogues and other places of Jewish life, have always been an expression of Jew-hatred. All of them are manifestations of antisemitism in different varieties, 
corroborated by religious doctrine, by pseudo-scientific theories, by referencing earlier sources, and by appealing to emotions of fear, anxiety, anger, and pride in the respective non-Jewish group opposing Judaism. Documenting these manifestations and, thus, tracing the transformational processes of antisemitism, is one of the aims and major focuses of the present volume. Modern and contemporary transformations of antisemitism in accordance with significant changes in modern information technology, especially with the rise of the internet, are dealt with in volume 5 of the present series in more detail and more extensively. ${ }^{6}$ Contributions to volume 5 are concerned with the question of what has enabled the transformation of contemporary antisemitism into a sentiment that is not only commonly accepted in all parts of all societies around the world but also is ever increasing. This increase in antisemitism is an imminent danger not only for Jewish communities around the globe but also questions and threatens the system of societal norms and values on a wholesale scale. While volume 5 focuses largely on the internet and modern media as the most important and main multipliers of contemporary Jew-hatred, contributions to the present volume deal more with the historical processes that have led to the current transformation of Jew-hatred into this new form of antisemitism in recent decades.

A third and last major topic of this volume, finally, is the question of what motivates antisemitism. As a response to societal or political changes, the motivations and intentions of antisemitic discrimination and persecution vary in different periods of time. They can only be understood as a combination of cultural reasons, for example, following certain societal or political ideological discourses, and of socio-psychological reasons, such as with regards to the abovementioned appeal to emotions like fear and anxiety. Opportunism and pressures to conform can also support the generation of a sentiment directed against an opposite socio-cultural group to strengthen one's self-identity. Socio-economic conditions, too, are an important factor and the curtailment of socio-economic advancement for certain groups within a society is a prevalent means to marginalise the group's overall influence onto a society. The mutability of motivations for antisemitism runs parallel to its history of constant transformation. This is why many of the contributions to the present volume reflect on manifestations of antisemitism and its intentions from an integrational perspective.

The multiple focuses of the present volume are also reflected in its structure. Contributions to the present volume fall into two different categories that call for a separate understanding and contextualisation. Some articles reflect on an-

6 Cf. A. Lange, K. Mayerhofer, D. Porat, and L. H. Schiffman, eds. Confronting Antisemitism in Modern Media, the Legal and Political Worlds, vol. 5 of An End to Antisemitism! (Berlin: De Gruyter, 2021). 
tisemitism and its historical tradition using a metatheoretical perspective. They try to comprehend antisemitism as cultural concept and unearth its origins, which can reach as far back as antiquity but still impact present times. These articles try to build bridges from contemporary to historical times in order to better understand current-day situations and events. Such metatheoretical articles can mostly be found in parts 1 and 2 on pre-modern times. On the other hand, the present volume features articles using classical historiographical approaches. They do not try to establish links between the present and the past, rather, they aim to document historical events and processes that have led to certain antisemitic incidents. Contributions with such a historiographical approach fall mostly into parts 3 and 4 of the present volume. Scholars of modern and contemporary history are faced with a multitude of sources and material that needs to be documented carefully in a first step to ensure accurate interpretation. The present volume represents both scholarly approaches and therein also aims at mirroring processes within the academic community scrutinizing the history of antisemitism. Recent trends in historical scholarship of antisemitism with regards to the understanding of new forms of antisemitism expressed in new media, such as the internet, are represented in the fifth and last part of the present volume. All of the various scholarly approaches reflected in the present volume lay the foundation for the three major topics that the present volume focuses on.

\section{Comprehending Antisemitism in Antiquity and Late Antiquity}

Antiquity and late antiquity are often neglected periods in the study of the history of antisemitism. Historical surveys of Jew-hatred mostly dedicate only brief chapters to it, and larger studies of the history of (late) ancient antisemitism are rare. This neglect is largely grounded in the claims that antisemitism is a modern invention and that Jew-hatred only played a marginal role in antiquity. The contributions in this part of the present volume thus address the question of whether antisemitism already existed in ancient and late ancient times and find different and diverse answers. Results vary in accordance with the understanding of antisemitism as a distinct form of racism and, more importantly, in accordance with the definition of racism itself. Many historians claim racism to be a concept closely connected to the history of trans-Atlantic slave trade and to the notion of biological differences between groups of people. Accordingly, they query the existence of antisemitism in ancient times as a form of hatred encompassing early concepts of identity that linked categories of both religion and race (Gruen). 
However, if racism and race are understood as resulting from the creation of a hierarchy between groups as their constitutional element, even early forms of Jew-hatred can be considered to be a form of racism, or, more precisely, antisemitism. Already in antiquity, Jews were subjected to different forms of cultural and physical persecution resulting from an overall claim about their general inferiority with regards to both their religion and nature. ${ }^{7}$ Most of the contributions to this part of the present volume try to shed more light onto this controversy. Based on contemporary source material from various backgrounds, these contributions engage with questions about the construction of a Christian identity in both antiquity and late antiquity (Rutgers). Dissociated from "real" Judaism, Christianity created a "hermeneutical" Judaism that was depicted as a demonic power of the past to empower a Christian supersessionist identity and the "True Israel." When Christianity gained power in the Roman Empire, Christian antisemitic ideology enabled the legal and physical persecution of Jews in an effort to construct and maintain an orthodox Christian identity against Jews and heretics being depicted as Jews. Accordingly, the articles in this part demonstrate that cultural, legal, and physical persecution as the three basic forms of antisemitic persecution existed already in antiquity. This points to the creation of a system of antisemitic traditions that since antiquity served to identify the Jewish "Other" (Lange). Therein, Jew-hatred served the construction of a Christian identity significantly. Additionally, the concept of a "hermeneutical Jew," discussed by Cohen ${ }^{8}$ and Nirenberg ${ }^{9}$ as a figure that assumed distinctive character and bodily characteristics and narrative significance in pre-modern thought and culture, can already be found in early Christian literature (Rutgers). A last contribution provides an important perspective for the study of medieval and modern antisemitism in identifying Visigothic canon law as laying the groundwork of racist antisemitism (Fredriksen).

Engaging with Early Christian Anti-Judaism, Leonard RuTGERS deals with the questions about what it was that ancient Christian antisemites were afraid of and why. He further investigates how ancient Christian Jew-hatred affected JewishChristian relations in antiquity generally and what were its structural and long-term effects. Regarding Jew-hatred, Rutgers finds four characteristics in ancient Christian texts: (1) antisemitic sentiments are "always there, humming in the background constantly" (33) as they can already be found in the earliest lay-

7 Cf. B. Isaac, The Invention of Racism in Classical Antiquity (Princeton: Princeton University Press, 2004), 1-52.

8 Cf. J. Cohen, Living Letters of the Law: Ideas of the Jew in Medieval Christianity (Berkeley: University of California Press, 1999), 10-19.

9 Cf. D. Nirenberg, Anti-Judaism: The Western Tradition (New York: Norton, 2013). 
ers of the New Testament and have influenced Christian thought ever since. (2) Notions directed against Jews appear in virtually all genres of ancient Christian literature. (3) Antisemitic thought was geographically evenly spread in ancient Christianity from Mesopotamia to Spain and expressed in all languages ancient Christians used. And, finally, (4) the Jews that ancient Christian texts agitate against are disconnected from real Jews and represent a hermeneutical construct. These "hermeneutical Jews" were constructed based on biblical exegesis and are thus "figments of scriptural imagination" (33). Christian theologians engaged with this kind of antisemitic negative-identity formation out of internal needs and aim thus mainly at internal consumption. The self-referential early Christian antisemitism was aimed mainly at a Christian in-group for purposes of identity construction. This supersessionist identity construction changed dramatically when Christianity became an official religion in the fourth century C.E. and thus had to deal with their Jewish neighbours on a manifest real-life level. While this experience did not lead ancient Christianity to question their concept of hermeneutical Judaism, it led to an explosion of antisemitic rhetoric and even antisemitic violence trying to communicate the hermeneutical construct of a theological obsolete Jewish "Other" into a historical reality. In this way, "the Fathers of the early Church were doing little else than laying the groundwork for letting anti-Jewish notions enter into the capillaries of Christian theology in ways that would profoundly influence and, in fact, spoil Jewish-Christian relations for much of the remainder of European history" (38).

In his article Jew-Hatred in Antiquity: Cultural, Legal, and Physical Forms of Antisemitic Persecution, Armin LANGE provides an exemplary survey of Jewhatred in antiquity. In this survey, he engages with three questions: (1) Did antisemitism exist in antiquity? (2) What forms of antisemitic persecution occurred in antiquity? (3) What relevance does ancient Jew-hatred have for latter forms of antisemitism? Lange argues that not only did Jew-hatred exist in antiquity, but it was even a popular theme in ancient Christian literature with prevalence in most Christian texts. From an ancient viewpoint, the absence of antisemitism can therefore only be argued if antisemitism is restricted to racist Jew-hatred alone. Racist Jew-hatred, however, is evident at least with the Visigothic kingdom in Spain. Already in antiquity, the three basic forms of how Jews were persecuted can be observed. Physical forms of persecution targeted the physical well-being of individual Jews or large Jewish groups and included (mass) killing of Jews, sometimes even on a regular basis. Legislative and judicial persecution discriminated against Jews by judicial means or by creating laws suppressing Jewish life and curtailing their social, economic, and political advancement. Cultural persecution aimed ultimately at the destruction of the cultural and religious identity of Jews and Judaism in antiquity and thus wanted to achieve a cul- 
tural genocide. Antisemites continue to practice all three forms of antisemitic persecution through today. These three forms of antisemitic persecution did not solely lay the ground work of medieval and modern antisemitism already in antiquity. Ancient pagan and Christian antisemites also created a system of antisemitic religious symbols, which, as Lange argues, served as guidance for antisemites and others on how to comprehend and perceive Jews. Communicated through various Christian channels, the antisemitic symbol system grew until today and is largely responsible for the reinvention of Jew-hatred in each epoch of history. Ancient pagan and Christian antisemites, thus, laid the ideological foundations on which even contemporary antisemites build.

Focusing on The Blood Libel and the Leper Libel: Ancient Antisemitism?, Erich S. GRUEN does not want to deny the existence of suspicion, disdain, and antipathy toward Jews in antiquity but thinks that they did not rise "to the level of antisemitism" (96). According to Gruen, the examples of the blood libel and the leper libel corroborate the claim that the impact of ancient Jewhatred was "far less consequential than is often realized" (96). As neither blood libel nor leper libel had any traction in the pagan world, Gruen regards Jew-hatred as a marginal phenomenon in pagan antiquity that cannot be described as antisemitism. This would be all the more true as antisemitism would be racist in nature and thus alien to antiquity.

In her article Divinity, Ethnicity, Identity: "Religion" as a Political Category in Christian Antiquity, Paula FREDRIKSEN points to the ethnic affiliation of religion in antiquity as a point often overlooked in the study of (ancient) antisemitism: “cult was an ethnic designation, and ethnicity was a cult designation" (102). In some cases, the scruples of Jews regarding the participation in a public cult irritated pagan ethnographers resulting in complaints about "Jewish atheótēs ('atheism') or asebeia ('impiety') or amixia (avoidance of others)” (106). While the cultural importance of pagan groups faded with the rise of Christian orthodoxy to the Roman state religion, polemics against Jews continued to exist and were repurposed for use by the later gentile churches. In addition, all nonOrthodox Christians became heretics and were regarded as a security threat to the Roman Empire. While gentile Christian polemical rhetoric targeting Jews served before to separate the gentile Christian from a demonised Jew in a binary system, the rhetoric contra Iudaeos was now applied to Christian heretics, which likened them to "the Jews." Jews, heretics, and pagans became thus "the objects of unwanted popular attention, legal harassment, and urban violence" (110). The reasons for the blooming Jew-hatred of late antiquity had thus "nothing directly to do with real Jews and everything to do with imperial efforts to define, mandate, and control 'orthodoxy"' (111). In this transition from the practical pluralism of antiquity to the statutory definition of religion in late antiquity, the legal 
situation of pagans, heretics, and Jews became thus permanently destabilised as religion was no longer an ethnic patrimony but a political choice. The next paradigm shift in the history of Jew-hatred followed with the conversion of the Visigothic Arian church to Roman Christianity in the years 587-589 C.E. The conversion was aimed at unifying an ethnically and religiously mixed kingdom. In uniting the Visigothic Spanish state with the Nicene Catholic church, the Visigoths reinterpreted the ancient ethnic affiliation of religion thus defining by legal means "the Goth" as a new ethnic identity for Hispano-Romans. In this process, the Jewish Romans of the Spanish Peninsula lost their legal and social standing and were forced to either convert or to become pariahs that were eventually banished. However, in later Visigothic canon law, converted Jews were not regarded as Christians but as "baptised Jews" or simply "Jews.” Visigothic canon law thus created a racist approach to Jew-hatred that had devastating consequences in the history of Judaism.

\section{Comprehending Antisemitism in the Middle Ages}

Most of the contributions in this part of the present volume deal less with historiographical descriptions of Jewish life in Medieval Western Europe. Rather, they inquire into medieval perceptions and, often times, imaginations of Jews from a pre-modern Christian perspective (Chazan, Mayerhofer, Offenberg). They operate with the concept of the "hermeneutical Jew." Antisemitic imagery in Medieval Christian Europe evolved much around this hermeneutical Jew who was imagined to represent every form of aberration from Christian doctrine. Jews were considered to be and, subsequently, constructed and described as blind believers in the wrong faith, stubbornly clinging to their scripture's literal and ultimate meaning, as hostile toward the saving role of Jesus Christ and the Virgin Mary's mercy, as economic exploiters in their roles as money-lenders, as asocial and members of a secluded group plotting against their Christian neighbours, and as wicked evil-doers, well-poisoners, and child murderers. In all of these stereotypes, commonly known from the Middle Ages even today, the link between emotionally charged aversion against a non-Christian "Other" and the process of rationalisation in various forms-theologically, scientifically, and legally-is apparent. Like in the previous part of this volume, the articles in this part, too, are concerned with the construction of Christian identity vis-à-vis their Jewish opposite who was claimed to be inferior, both on a spiritual and a manifest corporeal, societal, and political level. Aiming at unearthing the processes underlying this construction of Christian identity, the articles engage with medieval sources from the eleventh to the fifteenth centuries and analyse trans- 
mitted imagery, motifs, and narratives. A fourth article (Wiedl), in turn, takes a more historiographical approach in documenting medieval legislation that was directed against Jews and that curtailed their socio-economic advancement in a Western Christian society. However, this contribution too is based on the widely accepted assumption that antisemitic thoughts and actions were prevalent throughout the Middle Ages at all times and in all parts of society with medieval legislation being only one contributor to and manifestation of medieval Jewhatred, based on the understanding of Jews and Judaism as inferior and, thus, as subject to social, political, and legal subordination.

Robert CHAZAN traces the Evolution of Anti-Jewish Imagery in Medieval Christian Europe. Christian images of the Jews as a general threat to the societal order generated and fostered radical stereotypes directed against Jews which, even today, function as one of the foundations of modern and contemporary antisemitism. In his overview article, Chazan draws a line from Paul and his role in the Jesus movement to Augustine. Both had considered Jews and Judaism an aberration from the "True Israel," based on their misunderstanding and active rejection of God's revelation to them. Both positions, however, had hardly influenced Jewish daily life. It was not until the end of the first millennium that "western Christendom transformed itself from the weakest of the medieval religio-political power blocs into the strongest" (127) and brought about vast changes for the Jewish communities in North-Western Europe. The growing Christian communities in the European West and North pressed for a delineation of socio-political and socio-economic boundaries vis-à-vis their Jewish neighbours who had come to new parts in the Western world to find social and economic advancement. The Jewish "newcomers" were viewed with disfavour and as dissenting with Christian faith, followed by the evolution of a "new and baneful imagery of Judaism and Jews" (128) and resulting in a set of radically new negative stereotypes: a previous purported "deleterious Jewish religious impact" now transformed into notions of Jewish "societal harmfulness" beyond the religious sphere (130). The danger of these new stereotypes, however, lied, and continues to lie, in their intersectional power. Notions of economic exploitation in moneylending, or even more horrendous charges such as ritual murder linked with traditional Christian doctrine of the Jews as erroneous in their beliefs and guilty of the death of Jesus Christ. As such, these images laid the foundation for modern antisemitism and continue to flourish.

Kerstin MAYERHOFER engages with the role of cultural narratives in the process of formation of identity. She scrutinises the discourse of embodied inferiority and uses the example of the motif of Jewish "male menstruation" for her reflections on Inferiority Embodied: The "Men-struating” Jew and Pre-modern Notions of Identity and Difference. Based on the concept of racism and race as grounded in 
a proclaimed hierarchy of one group of people over another, Mayerhofer presents the "men-struating" Jew as one motif in a canon of imagery surrounding the "Jewish body," which, in turn, reflects back on pre-modern understandings of sex, gender, and, ultimately, race. In the example of the "men-struating” Jew, that is, the figure of a Jewish man afflicted with a regular flow of blood from his body, pre-modern Christian notions of difference and inferiority are reflected both on a cultural and on a "scientific" level. The example shows that premodern formation of identity is not solely based in culture or religion. Corporeal aspects, too, "served the construction as categories [of identity]," however, they were always "deeply connected with faith" (156). In presenting three sources from the thirteenth to the seventeenth centuries from a clerical, medical, and legal background, Mayerhofer uncovers the mechanisms that lie at the core of the establishment of the theme of an aberrant and inferior "Jewish body": universalisation, naturalisation, and normalisation. These mechanisms linked, first theologically, to mark all generations of Jews as responsible and guilty for the death of Jesus Christ, secondly, and "scientifically," to embody this hereditary guilt in images using somatic markers of distortedness conveying inferiority, and, finally, to "normalise and institutionalise the socio-political and socioeconomic marginalisation and discrimination" (153) of the Jews.

In her article "All the World's a Stage": Imagined Jewish Rituals in Medieval Christian Art and Drama, Sara OFFENBERG addresses blood libels and host desecration allegations with a special focus on their imagined character in art and drama. She argues that the public sphere, that is, visual representations of antagonist allegations against Jews, such as images, poems, or plays, helped them gain currency. She focuses on two examples in vernacular languages, the first being Alfonso X’s Cántigas de Santa Maria (1284), a compilation of stories and songs, sometimes beautifully illustrated. The Cántigas provide scholars with much information "about the anti-Jewish attitude of Christian Castilian society" (165) grounded in the vast prevalence of stories about icon profanation and host desecration. A second example is given with the Croxton Play of the Sacrament (1461) which, too, deals with a story about host desecration. In comparing both examples, Offenberg comes to the conclusion that although the narrative content of the stories and its transmitted themes do not vary much, the intentions of both sources differ with regards to their places of origin. While Jewish communities were still large and flourishing in late thirteenth-century Castile, medieval England could only report about Jews from a distant perspective, as Jews were no longer present on the British Isles since 1290. However, in both cases, Offenberg concludes, "the performance is intended for a Christian audience with a clear agenda," (177) and while it tells us less about the actual Jewish rituals of the time and place, it can help us to understand how Jewish 
daily life and ritual practice were perceived by the contemporary Christian majority society.

As mentioned above, Birgit WIEDL, in her article, takes a different approach. She engages with Anti-Jewish Legislation in the Middle Ages as a significant "part of medieval anti-Jewish thought and agenda to which it contributed both ideas and measures to act upon" (183). Her article is divided into three parts, the first deals with church law pertaining to the Jews. While church law had only limited effects on Jewish daily life, it can be identified as one of the most important transmitters of antisemitic stereotypes and narratives and supported their tradition well beyond the Middle Ages. In the second part about legislation of secular rulers, Wiedl carves out different strands of socio-political developments in different countries of the Christian Western Europe, which have led to a plurality of laws pertaining to the Jews. Countries that were influenced more strongly by church and canon law, such as England and France, also showed much tighter control of their Jewish communities. On the other hand, territories that would benefit from prospering Jewish communities, mostly financially but also in terms of imperial protection, such as in the Holy Roman Empire, were hesitant to incorporate anti-Jewish ideas into their legislation. In the last part of her article, Wiedl focuses on municipal and customary law, in which the Jews' status is "even more diverse" (200). The few written sources demonstrate especially hostile thoughts against Jews, often expressed in the most emotive language and accompanied by gruesome illustrations. All in all, Wiedl concludes, medieval laws pertaining to the Jews significantly contributed to the retention of ageold antisemitic stereotypes in both the legislation of the church and of emerging modern states. As such, they "prepared the ground for policies of later centuries, such as the church's demands of segregation and separation of Jewish and Christian living spaces, which, while only rarely carried out in the Middle Ages, were translated into the reality of the ghettos from the sixteenth century onwards" (209).

\section{Comprehending Antisemitism in Modern Times}

As stated above, the present volume, unfortunately, lacks contributions focusing on the turn of the Middle Ages into the early modern age. Renaissance and early modern engagement with Judaism however, is grounded largely in pre-modern tradition. Pre-modern sources were scrutinised, re-interpreted, and employed to corroborate modern humanist claims about religion, culture, economy, politics, and society in general. Still, efforts were taken to establish a specific cultural, religious, and social identity often by focusing on one's opposite. Christian 
identity in the Middle Ages, as we have seen, was very much shaped through a process of delineation from a non-Christian, mostly Jewish, "Other." Early modern thinkers largely followed this path, referencing earlier sources to authorise their own antagonist claims. As such, early modern writing is not a novel production but rather a re-production and re-shaping of earlier narratives of Jewhatred.

At the end of the eighteenth century, antisemitism gains momentum-a process that runs parallel with a response to the emancipation of the Jews in Western European societies. Modern Jew-hatred takes the form of a pseudo-scientific racism, corroborated by contemporary racist theories and nationalism and following the structural changes in and the advent of civil society. Discrimination against and persecution of Jews based on racial claims reached their highpoint in the National Socialist era and continued well beyond that time. The contributions in this part of the present volume scrutinise the processes that have led to the rise of antisemitism starting with the eighteenth century. As such, they take a more historiographical approach than the articles in the previous sections. However, they do not document socio-political processes from a systematic and general position only, rather, they also focus on individual influences (Wladika). Another focus lies on the Jewish perspective-how Jews have responded to sociopolitical changes in the nineteenth and twentieth centuries and how they have tried to oppose them (Levy, Rabinovici). This section also sheds light onto the influences of modern European racist propaganda onto non-European societies, much of which laid the foundations for current-day Jew-hatred, especially in the Arab world (Küntzel).

Michael WLADIKA analyses Georg Ritter von Schönerers Radikalisierung zum Rassenantisemiten vom Linzer Programm 1882 bis zur Gründung des "Verbandes der Deutschnationalen" 1885. The antisemitic agitation by Georg Ritter von Schönerer propagated pan-Germanism and German nationalism in Austria and influenced Adolf Hitler's antisemitism significantly. In his paper, Wladika traces the process of radicalisation that turned Schönerer from a purely far-right politician and opposer of political Catholicism into a racial antisemite. Five factors contributed to this transformation: (1) Schönerer's thorough engagement with Eugen Dühring's theories of Judaism as an inevitable enemy to all cultural nations, who in turn had to fiercely oppose this imminent threat. (2) This increasingly racial antisemitic notions that Schönerer took up led to his breach with the traditional nationalism and national socialism of his political predecessors. (3) Subsequently, other antisemites like Karl Lueger supported Schönerer in his political agitation, for example, in the case of the "Nordbahnskandal." (4) Schönerer's engagement in campaigns surrounding the election of the "Reichsrat" in 1885 served as a stage for his already increased racial antisemit- 
ism in delineation from German nationalism. (5) Finally, the formation of the Social Democratic as well as the Christian Social Party contributed to Schönerer's radicalisation as he feared these parties' threat to German nationalist efforts.

In his article, Richard S. LEvy documents The Defense against Antisemitism: Minor Victories, Major Defeats, 1890-1939. He traces Jewish responses against antisemitic attacks starting in the 1880s until their vast silencing with the rise of Nazi ideology. Especially in the early years, a collective defence was difficult to mount since Jewish communities were scattered around Germany, and it was mostly individuals who spoke out against antisemitic oppression, among them Theodor Mommsen. At the end of the nineteenth century, however, a first association for defence against antisemitism took shape in the Centralverein deutscher Staatsbürger jüdischen Glaubens [Central Association of German Citizens of Jewish Faith]. To ensure successful opposition against antisemitic ideology, associations like the Centralverein aimed at respectability through vast publication, at intervention into electoral politics, supporting candidates actively opposing antisemitism, and at judicial pursuit of antisemitic accusations and discrimination. These strategies helped to win some important victories before the outbreak of World War I. However, when antisemitism was radicalised by the lost war, their tools lost much of their power. Even though the Centralverein was among the first to recognise the growing and imminent Nazi threat, it found itself "relatively helpless" vis-à-vis a growing organisation and structuralizing of antisemitism. Using the example of the Centralverein, Levy concludes that the pressing danger of antisemitism lies first and foremost in its nature, which is a conflation of superstitions and stereotypical prejudice and systematic manifestation of such prejudice. He therefore calls for an alliance with antiantisemitic efforts from within the oppressed Jewish groups to stand up against oppression and discrimination in such a "prejudicial environment [...] from all walks of society" (242).

Doron RABINOVICI scrutinises The Jewish Response to Antisemitism in Austria Prior to the Anschluss. To properly understand the Jewish response to Austrian antisemitism, Rabinovici opens his article with an overview about Jewish life in Austria from the end of the nineteenth to the beginning of the twentieth century, focusing on Vienna as home for the largest Jewish community in the Habsburg monarchy. Prejudices surrounding Viennese Jews at the time radically fuelled contemporary antisemitism with their images of "the 'Jew' [...] as the leading representative of social change, a symbol of modern times as well as of old monotheism" (245), all corroborated by various nationalist efforts and forced assimilation. In this environment, Jewish political parties like the Union of Austrian Jews had formed to, first, "counter antisemitism in the courts of law, or through interventions and appeals to politicians” (246). Increasingly, however, they were 
considered not proactive and not Zionist enough and active Zionist Socialists soon gained power. They called for a "search for Jewish self-awareness" (248) instead of proving their loyalty to Austria and Germany and mobilized for a Jewish state in Palestine. Orthodox association on the other hand "tried to counter Christian Social antisemitism by stressing religious values and explaining that Judaism was [...] merely a faith" (250). At the advent of the "Anschluss," Austria's annexation into Nazi Germany, all of the parties, however, saw their efforts coming to a halt as Austrian antisemitism shifted from a "tacitly agreed general mood [...]" to "the overt credo of the bourgeois parties" (253). As a conclusion, Rabinovici calls for a better understanding of the situation prior to 1938 to, similarly, better understand the situation in Nazi Vienna following the "Anschluss." The "distinctive ambiance in Nazi Vienna" (254) had its foundation in antisemitic discrimination and legally corroborated the curtailment of the Jews' status way before the annexation into Nazi Germany, and the Jewish community's attempt to "safeguard its existence through patriotic compliance and loyalty” (254) had been in vain.

Matthias KüNTZEL engages with Nazi Propaganda in the Middle East and its Repercussions in the Postwar Period. The tradition of Islamic antisemitism is deeply rooted in European ideological models. In his article, Küntzel focuses on narratives of Jewish world conspiracy and their transfer from Nazi propaganda to the Muslim world which took place between 1937 and 1945. He understands Islamic antisemitism as a particular form of Jew-hatred "based on the fusion of Islamic anti-Judaism from the old scriptures with modern European antisemitism" (000). His article demonstrates how this particular form of Islamic antisemitism subsequently became popularised within the Arab world. The booklet Islam and Jewry, issued in 1937 and often attributed to the Grand Mufti of Jerusalem Mohammed Amin el-Husseini, serves Küntzel as one example for this transmission process. The Arabic-language program broadcast on Radio Zeesen outside of Berlin between 1939 and 1945 is a second example and considered the “most effective vehicle of Nazi propaganda” (263), as it helped to strengthen a reading of Islamic scripture that aimed at antisemitic agitation against Zionist ambitions. Both examples effectively demonstrate "Nazi Germany's efforts to incite Arabs against the Jews changed the perception of the Jews within Islamic societies" (270). Their aftereffects for the Arab world did not only pave the way for Islamic opposition against the Jews of Mandatory Palestine in 1948; they still prevail in today's Middle East as antisemitic rhetoric on both a political and a socio-cultural level. 


\section{Comprehending Shoah and Post-Shoah Antisemitism}

The articles in this part of the present volume deal with Shoah and post-Shoah antisemitism in Europe and in the United States. They are based on a larger question of whether the Shoah has to be regarded as a unique historical event or, rather, an event unprecedented with unique foundations. Understanding the Shoah as unprecedented and unique with regards to its totality and universality (Porat), efforts have been made to combat antisemitism and other forms of racism following World War II and its atrocities. While societies that have not been influenced by the experiences of World War II and the Shoah foster antisemitic attitudes in an undaunted continuity, antisemitism has been a taboo after the Nazi era for a long time, especially in societies that had suffered greatly from the crimes of the Nazi regime. In other countries, antisemitism has survived as a form of internalised self-hatred among Jewish communities themselves. This is largely grounded in political instalment of notions of nationality that pressed for the assimilation of religious and cultural diversity into a socio-political majority society (Cohen, Estraikh).

On the flip side of the coin, both history and the contributions in this part of the present volume document that as time passes and as countries and generations of people lose their understanding of the history of the Shoah and a direct connection to it, antisemitism became less of a taboo (Rosenfeld). This cannot only be observed in the United States but also in many countries around the world that have been home to Jews throughout history. Violent antisemitic incidents have significantly increased during the last half of a decade in connection with frustration from political establishments, ruling parties, and social inequity (Fireberg). While, following the Shoah, many efforts have been taken to combat institutionalised antisemitism, for example, in the Catholic Church (Silberstein), its permeability in all parts of society and its overall versatile nature and multiple transformations resulted in an overall atmosphere that is hostile toward Jews in any given part of our societies, regardless of whether or not a society had suffered more or less intensively during World War II.

In the first article of this section, Dina PORAT lays the foundation for further discussions as she asks the question Is the Holocaust a Unique Historical Event? A Debate between two Pillars of Holocaust Research and its Impact on the Study of Antisemitism. Porat follows the debate that has been ongoing for the past two decades in research around the world regarding the question of "whether the Holocaust was a unique historical event-meaning, an event possessing unique attributes that are characteristic of it alone-or a genocide that, although ex- 
treme, should nonetheless be located on the continuum of genocides that occurred before and after it" (275). To answer this question, Porat examines the views of two of the most prominent Israeli Holocaust researchers, Israel Gutman (1923-2013) and Yehuda Bauer (1926). She takes into consideration Gutman's and Bauer's personal family history as Holocaust survivors and Zionist activists. The assertion of the Holocaust's uniqueness, as proposed by Gutman, is often interconnected with Zionist efforts and served the latter "to reinforce the feeling that a unique Jewish society was being built in Israel in its aftermath, and that the world needed to recognize the terrible injustice" (288) that had been inflicted on European Jewry. Bauer, on the other hand, has argued that the Holocaust is not unique but an unprecedented event with unique foundations. The totality and universality of the Holocaust enterprise, as well as the "absence of rational motivating factors" (285), the amalgamation of racial theory and notions of the nature of the victim that resulted in the industrialisation of murder are components unique to the Holocaust in their combination albeit also appearing separately in other events of mass murder such as in Rwanda and in the Balkans. Concluding, Porat therefore strives to find a synthesis between the two different approaches and argues that there "is no fundamental contradiction between these two" (276). Rather, she calls for an understanding of the Holocaust as an unprecedented event which, however, should not serve to "disrespect or detract from the severity of other murders and atrocities or to exclude them from the discussion" (288). On the contrary, she argues that a "deeper exploration of the histories of other genocides and their outcomes, and their comparison to the Holocaust, can result in empathy for the suffering of the other" (288) and into shared efforts to combat antisemitism and other forms of racism.

In their article, Florette CoHen-ABAdy and Daniel Kaplin focus on Caribbean Jewry as a possible Model of Tolerance or Assimilation. While Jews had lived on Caribbean islands since the early sixteenth century, little is commonly known about their communal lives and, especially, about possible antisemitic hatred they face. Cohen and Kaplin, therefore, trace the history of Jewish communities on the islands of Cuba, Haiti, and on the Netherland Antilles, from their first settlements following expulsion from the Iberian Peninsula to the twenty-first century. Many of the Caribbean communities grew and flourished during the nineteenth and twentieth centuries. A special example is given with the Jewish community of Suriname as the "oldest Jewish community in the Western Hemisphere" (300), where Jews had been granted full religious and economic freedom already during the seventeenth century. Yet, Jewish life today is sparse in Suriname and most of the other places in the Caribbean. The decline had started in the late 1800s, following a large wave of emigration to the United States. As a second factor for the increasing disappearance of Jews 
in the Caribbean, immigration from Holocaust refugees is mentioned, who had no intention of establishing Jewish communities but rather gave in to the difficulties surrounding them in their new homes and ceased to maintain a Jewish way of life. Following emigration and assimilation, “classic antisemitism” (313) is largely absent in the Caribbean, a "conglomerate of islands and a multi-cultural society that favors tolerance and acceptance of all regardless of race or religion” (313). Concluding, Cohen and Kaplin, however, call for an investigation of the processes that led to the disappearance of Caribbean Jewry in the first place, which they see grounded in a differentiation "between tolerance/acceptance of difference and tolerance/acceptance of assimilation” (318). Caribbean Jews were largely invited to assimilate, rather than be accepted as different and had thus, subsequently, ceased to exist.

Gennady ESTRAIKH traces Jewish-Related Scholarship in the Soviet Union, 1953-1967, based on the example of Sholem Aleichem and Qumran. His article reveals how the ideological apparatus of the Soviet Union restricted and deformed Jewish-related academic scholarship following their political strategy of assimilating Jews into their own culture. This practice led to the vast loss of cultural memory with contemporary Jewry in post-Soviet countries and a lack of Jewish self-confidence. The missing access to books especially compounded the fostering of Soviet and post-Soviet Jewish national pride and identity. Additionally, "suppression of cultural memory by applying a straightjacket or an outright ban to works on ethnic history was seen as a way to dispel the rising tide of emigration," (342) starting in the 1970s and continuing until today. An even more important factor was the "glass ceiling" (342) that faced Jews with regards to their access to education, professional diversity, and social advancement. The examples of Sholem Aleichem and Qumran, however, show that Soviet efforts and oppressive policies against Jews, Judaism, and Jewish-related scholarship was not comprehensively effective. Both subjects were among the little aspects of Jewish cultural identity and memory that managed to survive and formed the basis for a new establishment of Jewish studies in the 1990s. Of course, however, they left and still leave little trace in Russian academia, and many Jewish scholars left Russia and other post-Soviet states to continue their studies elsewhere. This is why, sadly, Russian and post-Soviet Jewish studies "struggle to this day to put down roots through the layers of wasteland left from the Soviet period" (343).

Documenting Sister Rose Thering's Battle against Antisemitism, Alan SILBERSTEIN presents an example of an individual heartfelt desire to combat institutionalised antisemitism that society can still learn from even today. As a member of the Dominican order, Sister Rose Thering (1920-2006) devoted much of her life to the fight against injustice and discrimination against Jews 
in the Roman Catholic Church. For her PhD thesis, she had investigated the treatment of minorities in Catholic textbooks with a focus on the Jews, which in 1965 directly impacted the Declaration of the Second Vatican Council on the Relation of the Church with Non-Christian Religions, more commonly known as Nostra Aetate. Sister Rose had spoken of "the importance of mutual respect among the citizens of the American democracy" (354), which was taken up by members of the American Jewish Committee present at Second Vatican Ecumenical Council. While she acknowledged that antisemitism had not been a policy of the church, she pointed out that, rather, the antisemitism of the Roman Catholic Church was rooted in age-old Christian doctrine, teaching and preaching with its blaming of the Jews, pejorative mentioning of the term "Jew," with its "unjust or inaccurate comparisons of the Jewish religion with Christianity" (355) and its omissions of facts like Jesus Christ's Jewish ancestry. All of Sister Rose's examples found their way into Nostra Aetate, which now called for a "fraternal encounter" (357) between Christians and Jews. Subsequently, guidelines were issued for the changing of traditional teaching and preaching to rid textbooks of the portrayal of Jews and Israel as inferior to Christianity and, thus, illegitimate. Seeing her theories come into action, after Nostra Aetate, Sister Rose started to focus on Holocaust Education and on Education in Jewish-Christian Studies in the USA and Israel. Even today, her calls for the encouragement of dialogue, of academic rigor, and strategic commitment to the learning about antisemitism and unlearning of racist prejudices and judgements remain valid. Most of all, as Silberstein concludes, Sister Rose can serve as an example for courage, as she never lost hers during her long battle against antisemitism.

Alvin H. RosEnfELD investigates Antisemitism in Today's America demonstrating that it has been on the rise, especially during the last thirty years. He recognises that social antisemitism has always been part of the country's history and that American Jews have continuously been faced with discrimination and exclusion as well as with aggression and physical violence. During the 1930s, 1940s, and 1950s, American Jews had generally felt accepted and were mostly "fully integrated in virtually all strata of American life" (368). During the second half of the twentieth century, however, "America was entering a new and more threatening era, one marked by the emergence of a reenergized antisemitism together with overt forms of intolerance, bigotry, and hostility directed against others” (368-69). As a result, Jews were starting to feel more vulnerable, and this general disease is fuelled by contemporary attacks against them. A major part of Rosenfeld's article is therefore devoted to the three main areas of American social and political life where Jews are faced with antisemitic hatred and crimes: (1) general terror attacks that put the Jews at the centre of their attention; (2) anti-Zionism and antisemitism on university campuses; and (3) societal 
changes with the rise of White Nationalism, the Alt-Right, and White Supremacy, which gained momentum especially during the Trump era. Concluding, Rosenfeld calls to action in all these three fields, for recognizing antisemitism and developing strategies to monitor its manifestations, sponsoring academic research institutions to study contemporary antisemitism, scrutinizing the use of the internet to spread antisemitism, and protection of Jews by American legislation. All of these measures need to be brought together to avert what is happening to the Jews in America, which is a "newly agitated and more threatening situation" (386) than ever before. These present trends will have a "significant impact on the future of Jews, not only in America but around the world" (386).

In his article, Haim FIREBerg reviews Antisemitic Perceptions and Jewish Sense of Belonging. Following the general observation of the rise of antisemitic violence around the globe, but especially also in the European Union, Fireberg draws a comparison of contemporary antisemitism in four EU member states, between two from the west, France and the UK, and between two from the east, Hungary and Latvia. While the comparison between these four states results in a variety of differences, an overall finding is that the level of antisemitism "does not necessarily indicate the state of antisemitic perceptions" (404). In the UK and France, which record the highest number of violent antisemitic incidents, Jewish communities mostly have a strong self-confidence and feel largely "at home" in these countries. The same is true for Hungary and Latvia, albeit from an opposite angle-violent antisemitism is low, however, also Jewish selfperceptions are rather negative. Antisemitic perceptions are also strongly connected to national identity and the level of confidence in civil order. Frustration from political decision-making, ruling, and from social inequality, however, as Fireberg finds out, "are the major factors in adopting harsh perceptions about antisemitism" (404). Jews, in turn, feel especially insecure and abandoned wherever there is no political perspective to ensure their wellbeing in a country. Without a country's effort to recognise "that Jews are an important component of its society," levels of trust toward the country's government drop significantly, as the case of France has shown. The same can be observed in the United States in accordance with Trump presidency. Thus, the bigger picture reveals that antisemitism has significantly worsened in most of the countries all over the world during the last half decade. For the Jews, the "feelings of insecurity led to an increasing disbelief in the future of the community and has weakened the sense belonging to the nation" (400), especially in countries like France and Hungary. But also the examples from the UK and Latvia call to action, to confront and combat antisemitism to ensure secure living for Jews in countries where they have dwelled for centuries and have made themselves a proper home as proper members or European civic society. 


\section{Comprehending Anti-Zionism as a Virulent Form of "New Antisemitism"}

Forms of antisemitism that focus on Israel and its politics have already reached mainstream thinking. Anti-Zionism is one of the most eminent and most virulent forms of "New Antisemitism" that emerged in accordance with historical and socio-political changes in a world following both World Wars. Until today, however, its claims and narratives are deeply rooted in age-old perceptions, such as the hostility and greed of Jews. Antisemitic sentiments stay the same, even if they are framed as legitimate criticism against the politics of Israel. The articles in this part of the present volume therefore place a special focus on anti-Zionism and its dangers as a form of antisemitism that is easily adaptable and fits into every part of the political spectrum (Becker). The historical narrative of antisemitism, its versatile nature and motivation, as well as its multiple transformations are traced impressively in this last part of the present volume (Giesel). However, this volume can offer only limited room for studies focusing on this new form of antisemitism. As both anti-Zionism and other forms of "New Antisemitism" are often inextricably connected to modern media, especially to the internet (Markl), contributors to the present series have taken an effort to engage with these new forms more intensively in volume 5, Confronting Antisemitism in Modern Media, the Legal and Political Worlds. It is important, however, to understand, that these new forms of antisemitism do not represent a turning point in the history of antisemitism. Rather, they confirm antisemitism's consistent mutability and adaptability throughout time by attesting to one of its latest transformation.

Matthias J. BECKER engages with The German Left and Israel. Based on the general societal assumption that antisemitism is a phenomenon of the political right, Becker scrutinises the reproduction of traditional antisemitic stereotypes and the use of antisemitic metaphors in the German left, often covered as anti-Zionism. He uncovers two "demonizing maneuvers" (411): (1) The general association of Israel with colonialism and imperialism since the late 1960s. Both colonialism and imperialism are despised by the left, and subsequently left-wing European politics have shown a lot of solidarity with the Palestinians as Israel's oppressed opposite. Anti-Americanism, too, is an important factor, and contributes to the leftist's claim of Israel being "the bridgehead for the United States into the Arab world and partly interpret American support as the expression of the alleged Jewish global power" (411). (2) The German left has constructed a particular regional narrative of Israel as the "new Nazis" and compares the conflict in the Middle East with the Holocaust. This is both a political and psychological practice as through such "demonizing analogies, 
German atrocities are trivialized and identification with the German in-group takes place" (411). The identification of the Mideast conflict with the Holocaust helps Germans to emphasise their own history and sensitivity toward it with the result of feeling morally superior. Both anti-Zionist approaches are clearly antisemitic in a way that J. Améry has called "honourable,"10 since it opposes general anti-social behaviour such as colonialism and oppression. In his analysis, however, Becker demonstrates how the perceptions of Israel and the Mideast conflict vary in accordance with the socio-political background and motivation of those who reproduce these perceptions. While the motif of colonialism is especially important for the far-left, centre-left milieus, on the other hand, argue for human rights and call for Israel's secularisation. The varying rhetoric and its general mutability is one of the key factors not only for the popularity of new antisemitism but also for its special position and danger: when antisemitism is framed as legitimate criticism against the politics of Israel, it becomes easily acceptable in all parts of society.

In her article, Linda GIESEL analyses Comparisons between Israel and Nazi Germany in Contemporary German Discourse. She defines these comparisons as "communicative strategies to express defamation against individuals or groups of people and to generate outrage in the space of public communication" (443). The historical awareness of their recipients is exploited to file updated claims about Israeli politics and societal changes. This conflation of anti-Zionism and Nazi rhetoric in German discourse can be traced back to the beginning of the 1980s and functions in three different ways: (1) to dereference their own Nazi past; (2) to defame the State of Israel as a continuity of Nazi politics; and (3) to relativise Germany's guilt for the oppression of their victims, who, according to the discourse, now have turned into perpetrators themselves. To uncover these processes, Giesel has undertaken a linguistic corpus study including more than ten thousand emails addressed to the Embassy of Israel in Berlin and the Central Council of Jews in Germany, analysing their verbal antisemitic Nazi comparisons. A subsequent analysis reveals that "analogies between Israel and the German Nazi regime were realized predominantly as utterances without typical comparative connectives" (444). This means that, for example, the Israeli government is addressed with references to Hitler, Goebbels, the Wehrmacht, or the SS, therein focusing on the political agents and establishing a purported continuity between perpetrators of the past and present. Concomitantly, Palestine and Gaza as the targets of Israeli oppression are often connected to images of the Warsaw

10 J. Améry, "Der ehrbare Antisemitismus," in Werke: Aufsätze zur Politik und Zeitgeschichte, ed. S. Steiner (Stuttgart: Klett-Cotta, 2005 [1969]), 131. 
Ghetto or Auschwitz. What is especially dangerous about these comparisons, Giesel concludes, is their frequency and nonchalance. Without being challenged, utterances like these will subsequently pass with less frequent notice and habituation will set in.

Florian MARKL addresses The Depiction of Israel in the Media, often with catchphrases like "Israel Threatens to Defend Itself." Realizing that "the way Israel is depicted in the media's reporting exerts a tremendous influence on Europeans' attitude toward Israel" (465), Markl presents an analysis of Austrian media since 2011 as one example. This analysis shows how the coverage of news concerning Israel and Israeli politics often does not follow classic journalist standards. Rather, they "often draw a picture of Israel that is based on imbalanced and misleading reporting; the selective omission of facts; the application of double standards when judging Israeli behavior compared to that of other countries; and the presentation of their own biased attitudes toward Israel as if they were plain facts" (456-66). This leads to a general de-realisation in the media coverage concerning Israel that forms the foundation for a subsequent demonization of Israel and claims for its political de-legitimization. Attacks against Israel from the side of Palestine are often ignored in the media contributing to an image of Israel as ruthless in its own aggression without any legitimate motivation. Aggression and military action are subsequently claimed to be rooted in Israeli or Jewish "nature" and fuel narratives of the Jews and Israel as a worldwide danger.

Kerstin Mayerhofer is a PhD candidate at the University of Vienna's Institute of Jewish Studies and is co-advised at Queen Mary University of London. Her research focuses on perceptions of Jews in pre-modern Christian narrative with regards to representations of the Jewish body and gender. She has been working for the project "An End to Antisemitism!" since 2017 and has been serving as the managing editor of its multivolume conference proceedings.

Armin Lange is Professor of Second Temple Judaism at the University of Vienna's Institute of Jewish Studies as well as a corresponding member of the Austrian Academy of Sciences. His research specialises in ancient Judaism, the Dead Sea Scrolls, the textual criticism of the Hebrew Bible, ancient antisemitism, and the cultural and religious histories of antisemitism. He has published widely in all of these fields. 


\section{Bibliography}

Antonius Margaritha. Der gantz Jüdisch Glaub mit sampt ainer gründtlichen und warhafften Anzaygunge ... Augsburg: Heinrich Steiner, 1530.

Améry, Jean. “Der ehrbare Antisemitismus (1969).” In Werke: Aufsätze zur Politik und Zeitgeschichte, edited by Stephan Steiner, 131-40. Stuttgart: Klett-Cotta, 2005.

Bergmann, Werner. Geschichte des Antisemitismus. München: C. H. Beck, 2002.

Cohen, Jeremy. Living Letters of the Law: Ideas of the Jew in Medieval Christianity. Berkeley:

University of California Press, 1999.

Guillaumin, Colette. L'idéologie raciste: Genèse et langage actuel. Paris: Gallimard, 1972.

Heil, Johannes. “'Antijudaismus' und 'Antisemitismus': Begriffe als Bedeutungsträger.” Jahrbuch für Antisemitismusforschung 6 (1997): 92-114.

Isaac, Benjamin. The Invention of Racism in Classical Antiquity. Princeton: Princeton University Press, 2004.

Lange, Armin, Kerstin Mayerhofer, Dina Porat, and Lawrence H. Schiffman, eds. Comprehending and Confronting Antisemitism: A Multi-Faceted Approach. Volume 1 of An End to Antisemitism! Berlin: De Gruyter, 2019.

Lange, Armin, Kerstin Mayerhofer, Dina Porat, and Lawrence H. Schiffman, eds. Confronting Antisemitism from the Perspectives of Christianity, Islam, and Judaism. Volume 2 of An End to Antisemitism! Berlin: De Gruyter, 2020.

Lange, Armin, Kerstin Mayerhofer, Dina Porat, and Lawrence H. Schiffman, eds. Confronting Antisemitism in Modern Media, the Legal and Political Worlds. Volume 5 of An End to Antisemitism! Berlin: De Gruyter, 2021.

Langmuir, Gavin I. Toward a Definition of Antisemitism. Berkeley: University of California Press, 1990.

Nipperdey, Thomas, and Reinhard Rürup. "Antisemitismus.” In Geschichtliche Grundbegriffe: Historisches Lexikon zur politisch-sozialen Sprache in Deutschland, edited by Otto Brunner, Werner Conze, and Reinhart Koselleck, 129-53. Stuttgart: Klett-Cotta, 1972. Nirenberg, David. Anti-Judaism: The Western Tradition. New York: Norton, 2013. Wistrich, Robert S. Antisemitism: The Longest Hatred. London: Methuen, 1991. 
